\title{
EFEKTIVITAS COGNITIVE READING STRATEGIES PADA PENINGKATAN PRESTASI AKADEMIK MAHASISWA
}

\author{
Oleh: \\ Saifullah \& Abd Mughni \\ Universitas Ibrahimy Situbondo, Indonesia \\ saivul.07@gmail.com \& abd.mughni@gmail.com
}

\begin{abstract}
:
This study aims to test the effect of cognitive reading strategies to enhance undergraduate students academic achievement. This study used quasi-experimental alternative-treatment design with pretest. There are 63 undergraduate students in psychology class as a subject. The research data obtained from reading comprehension achievement tests and prior knowledge test as co-variable. The reading comprehension achievement tests and prior knowledge test score compare before and after learning process and tested using Ancoca. The results showed that the cognitive reading strategies was significantly improve undergraduate students academic achievement of the experimental group than the control group. For the cognitive reading strategies feasible for implementation.
\end{abstract}

Keyword: Membaca Pemahaman, Strategi Kognitif, Pengetahuan Awal, Prestasi Akademik

\section{A. Pendahuluan}

Salah satu tujuan pendidikan yaitu mengembangkan kemampuan kognitif pembelajar. Pada jenjang perguruan tinggi, kemampuan kognitif mahasiswa merupakan kemampuan dasar untuk menguasai materi perkuliahan. Mahasiswa secara umum, perkembangan kognitifnya berada pada level perkembangan opersional formal. Pada tingkatan ini, mereka sudah mampu menerapakan keenam tingkatan domain kognitif Bloom, yaitu; mengingat, memahami, menerapkan, analisis, sentesis, dan evaluasi. ${ }^{1}$

Salah satu kegiatan yang memberikan kontribusi besar dalam proses mengakuisisi pengetahuan mahasiswa yaitu melalui kegiatan

1 Saifullah, Pengaruh Metode Learning Together Terhadap Prestasi Pemahaman Bacaan Siswa Pada Mata Pelajaran Bahasa Inggris di SMP, Tesis, Yogyakarta, UGM, 2012 20. 
membaca. Membaca merupakan proses interaksi psikologis pembaca dalam memahami lambang-lambang bahasa tulis untuk memperoleh makna dari wacana. ${ }^{2}$ Setidaknya terdapat tiga kegiatan dalam membaca, yaitu komunikasi, transfer informasi, dan transfer pengetahuan. ${ }^{3}$ Membaca merupakan proses interaksi antara pembaca dengan teks/wacana untuk menterjemahkan bahasa-bahasa penulis kemudian membangun makna atas pemikiran penulis sehingga pembaca memperoleh pemahaman baru yang lebih representatif. ${ }^{4}$ Aktivitas membaca dapat dipahami sebagai kerja mental yang berfungsi sebagai sarana pemerolehan informasi dan pengetahuan baru. Informasi dan pengetahuan baru yang diperoleh oleh pembaca kemudian digunakan sebagai dasar menjalankan seluruh aktivitas kehidupannya. Melalui membaca, pembaca dapat meningkatkan keterampilan berfikir kritis dan analitis setiap menghadapi problem yang menuntut penyelesaian masalah.

Pemerolehan beberepa manfaat dari kegiatan membaca tersebut dapat dicapai melalui penggunaan keterampilan membaca dan kemampuan membaca pemahaman (reading comphrehension). Melalui membaca pemahaman, pembaca dapat mengoptimalisasikan pemerolehan makna informasi yang hendak dicapai. ${ }^{5}$ Para teoritisi psikologi kognitif bersepakat bahwa membaca pemahaman melibatkan kerja fisik dan kognitif yang kompleks untuk mengorganisir berbagai informasi yang diterima untuk kemudian direkonstruksi menjadi sebuah informasi yang penuh makna. Membaca pemahaman merupakan proses berkelanjutan dalam menggali dan mengkonstruksi makna wacana ${ }^{6}$ sebagai representasi dari bacaan yang dibacanya7. Membaca pemahaman melibatkan kerja motorik seperti gerak mata ${ }^{8}$ dan proses kognitif yang kompleks dalam

2 Ibid, 18.

3 Suriah Ampuni, Proses Kognitif Pemahaman Bacaan, Buletin Psikologi, Th. VI, No. 2, 1998, 16.

4 Imam Suyitno, Cognitive Strategies Use in Reading Comprehension and its Contributions to Students' Achievement, IAFOR Journal of Education, Volume, 5, 3, 2017, 109.

${ }^{5}$ Ampuni, Op. Cit., 17.

6 Catherine Snow, Chair, Reading for Understanding: Toward a Research and Development Program in Reading Comprehension, RAND, South Hayes Street, Arlington, 2002, 11.

7 Ahmet Şahan, Cognititive Reading Comprehension Strategies Employed by ELT Students, Sosyal Bilimler Enstitüsü Dergisi Sayı, 3, 2012, 2.

8 Khalimi Romansyah, Strategi Membaca Pemahaman yang Efektif dan Efisien, DEIKSIS - Jurnal Pendidikan Bahasa dan Sastra Indonesia, 2017, 70.

$224 \mid$ JURNAL LISAN AL-HAL 
mentransfer dan mengolah ide-ide $^{9}$ dari wacana yang disampaikan penulis ${ }^{10}$ untuk kemudian mengintegrasikan berbagai informasi tersebut menjadi sebuah pemahaman yang utuh ${ }^{11}$.

Membaca pemahaman merupakan kemampuan higher-level process dimana pembaca mengelaborasi makna, mengorganisasikan berbagai informasi, dan melakukan evaluasi terhadap informasi yang terdapat dalam wacana. ${ }^{12}$ Kemampuan higher-level process dapat dicapai apabila pembaca memiliki keterampilan dasar ${ }^{13}$ dan menggunakan strategi yang baik dan efektif ${ }^{14}$. Strategi belajar merupakan kerja kognitif yaitu perencanaan yang berorientasi pada proses mencapai tujuan belajar. ${ }^{15}$ Startegi belajar merupakan prosedur yang digunakan pembelajar dalam mengerjakan tugas-tugas belajar. ${ }^{16}$ Strategi belajar secara sadar dipilih sebagai alat untuk melibatkan diri secara aktif dalam mengatur dan mengarahkan belajarnya untuk mencapai tujuan belajar yang telah ditetapkan.

Kegiatan membaca dan membaca pemahaman juga merupakan bagian dari kegiatan belajar yang bertujuan memperoleh pengetahuan dari apa yang dibacanya. Tujuan dapat dicapai secara optimal, apabila pembaca menerapkan strategi-strategi dalam membaca untuk memahami isi bacaannya. Chamot ${ }^{17}$ dan Oxford $^{18}$, menyebutkan tiga strategi membaca pemahaman yaitu; cognitive reading strategies, metacognitive reading strategies, dan socio-affective reading strategies.

${ }^{9}$ Donna Park, A study of the Goodman socio-psycholinguistic approach to beginning reading instruction in a frstgrade classroom, ScholarWorks@UMass Amherst, University of Massachusets Amherst, 2014,14.

10 Snow, Op.Cit. 103.

11 Panayiota Kendeou \& Paul van den BroeK, The effects of prior knowledge and text structure on comprehension processes during reading of scientific texts, Memory \& Cognition, 2007, 1575.

12 Saifullah, Op. Cit. 16.

13 Michael Pressley, John G. Borkowski \& Wolfgang Schneider, Cognitive Strategies: Good Strategy User Coordinate Metacognition and Knowledge, Annals of Cbild Development, Vol. 4, 1987, 91.

${ }^{14}$ Romansyah, Op. Cit. 74.

15 Dale H. Schunk, Learning theories: an educational perspective. $6^{\text {th }}$ ed. Pearson Education, Inc. 2012, 417.

16 Anna Uhl Chamot, Language Learning Strategy Instruction: Current Issues and Research, Annual Review of Applied Linguistics, 25, 2005, 112.

17 Anna Uhl Chamot, Teaching Learning Strategies to Language Students. U.S Departemnt of Education. Educational Resources Information Center (ERIC). 1998, 24.

18 Rebecca L. Oxford, Language Learning Styles and Strategies: An Overview. Web.ntpu.tw/ language/workshop/read2. 2013, 12. 
Cognitive reading strategies (strategi kognitif) adalah kemampuan pembaca untuk memanipulasi materi belajar secara langsung, melakukan penalaran, analisis, membuat catatan atau catatan pinggir, meringkas, membuat sistesis, dan mereorganisasi informasi untuk membangun skema yang kuat atau struktur pengetahuan. ${ }^{19}$ Metacognitive reading strategies merujuk pada proses eksekutif yang digunakan oleh pembaca dalam merencanakan, memonitor, serta melakukan evaluasi tugas-tugas belajar ${ }^{20}$, sedangkan strategi socio-affective merupakan kemampuan pembaca dalam berinteraksi dalam proses pembelajan ${ }^{21}$.

Pada penelitian ini, peneliti menfokuskan kajian penelitian pada strategi kognitif dalam membaca pemahaman. Strategi ini dipilih karena sangat penting dalam mempelajari bahasa yang dianggap baru oleh mahasiswa. Pada penelitian ini, buku acuan yang digunakan oleh mahasiswa sebagai sumber belajar adalah buku berbahasa Inggris. Strategi kognitif merupakan proses mental terkait dengan pemerosesan informasi yang bertujuan untuk menyimpan, memperoleh mengambil dan atau menggunakan informasi. ${ }^{22}$ Strategi kognitif merujuk pada pendekatan instruksional yang digunakan dalam proses pembelajaran seperti analisis langsung, transformasi informasi, dan membuat sintesis. ${ }^{23}$

Strategi kognitif merupakan kerja mental terkait pemerosesan informasi yang dilakukan oleh pembaca dalam upayanya memperoleh berbagai informasi untuk kemudian disimpan dalam memori jangka panjang dan kegiatan memanggil kembali informasi tersebut untuk digunakan. ${ }^{24}$ Penggunaan strategi kognitif membantu pembaca mampu megelaborasi dan merelasikan berbagi informasi yang tersimpan dalam memori.25 Elaborasi dilakukan oleh pembaca untuk memindahkan informasi dari memori jangka pendek ke memori jangka panjang dengan cara menggabungkan informasi baru dengan pengetahuan yang telah

19 Ibid

20 J. Michael O'Malley, Anna Uhl Chamot, \& Lisa Kupper, The Role of Learning Strategies in Second Language Acquisition: Strategy Use by Students of English. U.S. Army Research Institute for the Behavioral and Social Sciences, 1987, 4.

21 Chamot, Op. Cit., 1998, 24.

22 Yesim Ozek \& Muharrem Civelek, A Study on the Use of Cognitive Reading Strategies by ELT Students, The Asian EFL Journal Professional Teachers Articles, 2006, 24.

23 Lisa Jean Lawrence, Cognitive and Metacognitive Reading Strategies Revised: Implication for Instruction, The Reading Matrix, Vol. 7, No. 3, 2007, 56.

24 Williams, M. \& Burden, R. L, Psychology for language teachers: A social constructivist approach, Cambridge, Cambridge University Press, 1997, 148.

25 J. Michael O'Malley, Anna U. Chamot, \& Lisa Kupper, Op. Cit, 4.

226 JURNAL LISAN AL-HAL 
dimiliki pembaca yang tersimpan dalam memori jangka panjang.

Weinstein dan Mayer, menggambarkan strategi kognitif sebagai dua aktivitas yang tidak terpisahkan antara perilaku dan proses kognitif. ${ }^{26}$ Aktivitas perilaku dimaksud seperti; membuat catatan, menelaah teks, menemukan dan mengecek jawaban, serta merangkum, sedangkan proses kognitif seperti; mengaktivasi pengetauan, memonitor pemahaman, dan melakukan inferensi atau menarik kesimpulan dari makna wacana. Menurut Sahan, terdapat beberapa strategi kognitif yang umum digunakan oleh pembaca untuk memperoleh pemahaman yang utuh dari suatu wacana, yaitu; pengulangan (membaca berulang-ulang), mmbuat ringkasan, menggunakan penalaran deduktif, memprediksi informasi atau makna tersirat dalam teks, berfikir analitis, menghubungkan makna teks dengan konteks, membuat catatan atau catatan pinggir, mempraktikkan kemampuan yang spesifik seperti penguasaan struktur bahasa atau kosa kata. ${ }^{27}$ Strategi kognitif merujuk kepada strategi instruksional yang digunakan oleh pembaca untuk menganalisis dan memecahkan masalah belajar secara langsung, mentransformasi atau bersintesis tentang berbagai materi pembelajaran untuk memperoleh pengetahuan baru.

Penggunaan strategi kognitif memberikan peluang bagi pembaca untuk menggali dan mengkonstruk pemahaman dari wacana. Strategi kognitif dapat membantu pembaca memanipulasi secara langsung aktivitas belajarnya guna memperoleh hasil belajar yang optimal. ${ }^{28}$ Menurut Garner, penggunaaan strategi secara terencana serta aktif dalam melakukan perbaikan terhadap kegagalan kognitif akan membantu mempermudah pembaca meneyelesaikan tugas-tugas belajar. ${ }^{29}$ Strategi kognitif dapat dipahami sebagai suatu proses bagi pembaca melakukan kontrol terhadap strategi yang digunakan untuk meningkatkan performansi belajarnya. Penggunaan strategi tersebut bertujuan untuk memanggil kembali pengetahuan yang dimiliki sebelumnya sebagai cara memahami suatu teks atau wacana untuk memperoleh pengetahuan baru. Beberapa temuan penelitian membuktikan bahwa penggunaan strategi kognitif dalam membaca pemahaman secara signifikan dapat meningkatkan; kemampuan mahasiswa menyelesaikan tugas-tugas yang

${ }^{26}$ Fransisco Cano-Garcia \& Fernando Justicia-Justicia, Learning strategies, styles and approaches: an analysis of their interrelationships, Higher Education, 27, 1994, 240.

27 Sahan, Op. Cit. 5.

28 Nur Intan Asmara, An Analysis of Cognitive Reading Strategies Used in Reading Comprehension, Advances in Social Science Education and Humanities Research (ASSEHR), Vol. 82, 2017, 304.

${ }^{29}$ Sahan, Op. Cit., 3. 
sulit dan mampu mengidentifikasi informasi informasi spesifik ${ }^{30}$, siswa terampil menulis wacana dalam bentuk deskriptif31, siswa terampil atau mahir dalam membaca ${ }^{32}$, dan prestasi belajar siswa ${ }^{33}$.

Strategi kognitif sebagai kerja mental atau proses kognitif terkait erat dengan pemerosesan informasi. Salah satu unit kerja pemerosesan informasi yaitu memanggil kembali informasi yang telah tersimpan dalam memori jangka panjang. Informasi yang tersimpan merupakan pengetahuan awal (prior knowledge) yang mempermudah pembaca memahami informasi yang terdapat pada sebuah bacaan. Pengetahuan awal merupakan pengetahuan yang dimiliki pembaca berupa pengalaman dan pengetahuan umum yang berhubungan dengan topik wacana yang digunakan oleh pembaca untuk memahami isi wacana. ${ }^{34}$

Pengetahuan awal merupakan kemampuan pembaca dalam mengarahkan informasi, pengetahuan, emosi, dan budaya dalam bentuk skemata yang diperoleh dari pengalaman atau membaca. ${ }^{35}$ Goodman dan Page, menyatakan bahwa pengetahuan awal memiliki kontribusi yang signifikan dalam meningkatkan pemahaman pembaca terhadap wacana yang dibacanya. ${ }^{36}$ Pembaca yang telah memiliki pengetahuan awal yang tinggi dapat membantu mekanisme kerja kognitif,37 mudah memahmai isi wacana, ${ }^{38}$ menghubungkan pengetahuan awal dengan informasi baru, ${ }^{39}$

30 Sahan, Op. Cit, 1.

31 Fauzul Etfita, Improving Studens' Reading Comprehension of Descriptive Texts Through Cognitive Strategy at Grade VII-2 of SMPN 1 Indara Praja Tembilahan, Lingua Didaktika, Vol. 7. 2, 2014, 75.

32 Ozek \& Civelek, Op. Cit,1.

33 Anne Ratna S, The Use of Cognitive Reading Strategies to Enhance EFL Students' Reading Comprehension, International Journal of Education, Vol. 2, 1, 2014, 9.

34 Noldy Pelengkahu, Hubungan antara Pengetahuan Awal dan Penguasaan Kosakata Terhadap Keterampilan Membaca Pemahamn Mahasiswa, Jurnal Pendidikan dan Kebudayaan, 063, 12, 2006, 881.

35 Ibrahim Mohamed Alfaki \& Ahmed Gumaa Siddiek, The Role of Background Knowledge in Enhancing Reading Comprehension, World Journal of English Language, 3, 4, $2013,43$.

36 Kenneth S. Goodman \& William D. Page, Reading Comprehension Programs: Theoretical Bases of Reading Comprehension Instruction in the Middle, Grades, Revised Final Report. National Institute of Education United States Department of Health, Education and Welfare. 1987, 119.

37 Kendeou \& BroeK, Op. Cit, 1567.

38 Maria Novary Ngabut, Reading Theories and Reading Comprehension, Journal on English as a Foreign Language, Vol. 5, 2015, 30.

${ }^{39}$ Carol Booth Olson \& Robert Land, A Cognitive Strategies Approach to Reading and Writing Instruction for English Language Learners in Secondary School, Research in the 228 JURNAL LISAN AL-HAL 
mengintegrasikan fakta-fakta dalam teks dengan pengetahuan lama untuk melakukan hal-hal seperti; mengidentifikasi pikiran utama teks, inferensi, dan memprediksi. ${ }^{40}$

Ketika membaca, pembaca akan menfokuskan perhatiannya pada wacana dan menghubungkan informasi baru dengan informasi lama untuk melakukan inferensi atau penafsiran terhadap isi wacana, sehingga pembaca memperoleh pengalaman baru atau pengetahuan baru. Sementara itu, bagi pembaca yang memiliki sedikit pengetahuan awal, ia akan mengalami kesulitan dalam menghubungkan informasi-informasi baru yang didapatinya. Hal ini senada dengan pendapat Schunk, bahwa tanpa latar belakang pengetahuan, pembaca akan mengalami kesulitan dalam dua hal, yaitu memahami substansi wacana dan menyimpannya dalam memori jangka panjang. ${ }^{41}$ Beberapa hasil penelitian membuktikan bahwa latar belakang pengetahuan secara sangat signifikan berpengaruh terhadap pemahaman pembaca. ${ }^{42}$ Pada penelitian ini, peneliti ingin menguji secara statistik teori yang menyatakan bahwa strategi kognitif secara signifikan berpengaruh terhadap peningkatan membaca pemahaman pembaca dengan melakukan pengendalian terhadap variabel pengetahuan awal untuk menjaga validitas internal hasil penelitian. Hal ini dilakukan karena secara teoritis variabel ini memiliki sumbangan yang sangat signifikan terhadap membaca pemahaman.

Berdasar kajian teoritis dan beberapa temuan penelitian tentang keunggulan dari penggunaan strategi kognitif dalam membaca pemahaman yang telah diuraikan di awal, maka hipotesis yang diajukan pada penelitian ini adalah strategi kognitif secara signifikan efektif dapat meningkatkan prestasi akademik mahasiswa pada matakuliah Pengantar Psikologi di Universitas A Situbondo.

\section{B. Metode Penelitian}

Subjek penelitian sebanyak 63 mahasiswa (30 mahasiswa kelompok ekpserimen dan 33 mahasiswa kelompok kontrol) yang mengikuti matakuliah Pengantar Psikologi pada Fakultas Dakwah

Teaching of English, Vol. 41, 3, 2007, 279.

40 Muhammad Rusni, Ikhwan Sawaty, \& Elihami, The Cognitive Strategies through the Reading Comprehension in Islamic Education, Prosiding Konferensi Nasional Ke- 6 Asosiasi Program Pascasarjana Perguruan Tinggi Muhammadiyah 'Aisyiyah (APPPTMA), 2017, 127.

41 Schunk, Op. Cit, 194.

42 Pelengkahu, Op. Cit, 875. 
Universitas A di Situbondo tahun akademik 2017/2018. Variabel penelitian terdiri dari variabel perlakuan strategi kognitif dan variabel prestasi akademik. Desain penelitian ini menggunakan rancangan eksperimen kuasi alternative group design dengan memberikan pre-test dan post-test pada kelompok eksperimen dan kelompok kontrol. Menurut Cook dan Campell, rancangan eksperimen kuasi dapat dilakukan apabila kelompok sudah terbentuk terlebih dahulu dan sulit untuk dilakukan acak individu (nonrandom assigment). ${ }^{43}$

Data diperoleh melalui alat pengumpul data yaitu tes pengetahuan awal dan tes membaca pemahaman yang disusun oleh peneliti. Tes pengetahuan awal merupakan alat tes yang digunakan untuk mengukur kemampuan awal mahasiswa yang diberikan sebelum perlakuan diberikan pada kelompok eksperimen (pre-test). Sedangkan tes membaca pemahaman / tes prestasi akdemik diberikan pada saat perlakuan terhadap kelompok eksperimen telah selesai (post-test). Guna kepentingan penelitian ini, kedua alat ukur tersebut diujicobakan pada 35 responden mahasiswa di tempat penelitian ini dilakukan untuk mengetahui validitas dan reliabilitas kedua alat ukur dimaksud. Estimasi validitas kedua alat ukur dilakukan melalui professional judgemet untuk menganalisis isi dari alat ukur (content analysis). Sedangkan untuk menguji reliabilitas aitemaitem pada alat ukur tesebut dilakukan dengan bantuan alat bantu statistik. Hasil dari analisis terhadap kedua alat ukur tersebut diperoleh koefisien reliabilitas alpha $=0,83$ untuk tes pengetahuan awal dan tes membaca pemahaman / prestasi akademik dengan besaran koefisien reliabilitas alpha $=0,87$.

Adapun proses pelaksanaan penelitian pada penelitian ini, yaitu sebagai berikut; 1) sebelum kelompok eksperimen diberikan perlakuan, kedua kelompok penelitian baik kelompok eksperimen maupun kelompok kontrol diukur terlebih dahulu (pre-test) dengan alat tes membaca pemahaman sebagai pengetahuan awal mahasiswa, 2) materi perkuliahan disesuaikan dengan kontrak belajar di awal perkuliahan dimulai yang telah disepakati bersama mahasiswa. Buku referensi yang digunakan, yaitu "Introduction to Psychology Adapted by: College of Lake County Faculty: Martha Lally and Suzanne Valentine-Frenc", 3) pelaksanaan eksperimentasi dengan menerapkan strategi kognitif pada kelompok eksperimen sebanyak empat kali pertemuan; yaitu pertemuan kesembilan untuk membahas materi chapter 4 tentang learning, dilanjut pertemuan

43 Thomas Dicky Hastjarjo, Kausalitas Menurut Tradisi Donald Campbell, Bulletin Psikologi, 29, 1, 2015, 5.

230 JURNAL LISAN AL-HAL 
kesepuluh membahas materi chapter 5 tentang memory and cognition, kemudian pertemuan kesebelas membahas materi chapter 6 intelligence and language, dan pertemuan terahir sebagai perlakuan terahir membahas materi chapter 7 tentang lifespan development, 4) sementara itu, pada kelompok kontrol perkuliahan berjalan seperti semula dimana mahasiswa tidak diberikan strategi apapun dalam membaca materi perkuliahan yang sudah didistribusikan seperti pada kelompok eksperimen, 5) setelah perlakuan selesai, peneliti melakukan pengukuran kembali pada kedua kelompok penelitian (post-test) dengan menggunakan alat ukur yang berbeda substansi dari alat ukur pertama, dan 6) skor yang diperoleh dari dua kali pengukuran tersebut kemudian diuji pengaruhnya dengan menggunakan analysis of covariance (Ancova). Teknik analisis dengan menggunakan Ancova bertujuan untuk menurunkan error variance dengan cara mengendalikan pengaruh variabel kontrol (skor pre-test atau variabel pengetahuan awal) yang diasumsikan dapat mencemari hasil penelitian sehingga penelitian menjadi bias atau validitas internal dari hasil penelitian ini diragukan kebenarannya.

\section{Hasil}

Sebelum dilakukan uji statistik, terlebih dahulu dilakukan uji prasyarat, yaitu: pertama, uji normalitas distribusi skor pre-test dan posttest. Hasil uji normalitas menunjukkan bahwa data penelitian terdistribusi normal dengan nilai $\mathrm{Z}_{\mathrm{k}-\mathrm{s}}=12,75$ dengan $\mathrm{p}=0,025$ untuk skor pre-test, sedangkan untuk skor post-test diperoleh nilai $\mathrm{Z}_{\mathrm{k}-\mathrm{s}}=14,78$ dengan $\mathrm{p}=$ 0,14, dengan demikian dapat disimpulkan bahwa data tersebar secara homogen. Ketiga, uji verifikasi persyaratan analisis Ancova yang mempersyaratkan adanya hubungan yang linier antara kovarian dengan variabel dependen dimana hasil dari analisis korelasinya juga mengharuskan tidak terdapat interaksi antara kovarian dengan variabel perlakuan (Widhiarso, 2011). Hasil uji prasyarat menunjukkan terdapat korelasi yang signifikan antara variabel pengetahuan awal (pre-test) dengan prestasi akademik setelah diberikan perlakuan $(r=0,578 ; p<0,01)$. Sementara itu hasil uji interaksi memperlihatkan bahwa terdapat interaksi antara kelompok eksperimen dengan varibel kontrol yang dibuktikan dengan nilai $F=9,019$ ( $p>0,05)$.

Hasil uji statistik menggunakan Ancova diperoleh rerata prestasi akademik kelompok eksperimen $(M=16,45 ; S D=5,73)$ lebih tinggi dari kelompok kontrol $(M=13,16$; $S D=5,33)$. Hasil lain juga menemukan bahwa dampak perlakuan strategi kognitif pada kelompok eksperimen secara 
signifikan dapat meningkatkan prestasi akademik dibandingkan kelompok kontrol dengan nila $F=8,136 ; p<0,01$. Sumbangan efektif pada peningkatan prestasi akademik mahasiswa bagi kelompok eksperimen sebesar 0,34\%.

Kontrol secara statistik terhadap variabel pengetahuan awal pada penelitian ini bertujuan menghilangkan pengaruh variabel tersebut terhadap variabel dependen atau ingin menjaga kemurnian hasil penelitian, bahwa penelitian ini memang dipengaruhi oleh akibat adanya perlakuan yang diberikan pada kelompok eksperimen, bukan karena faktor-faktor lain seperti variabel pengetahuan awal. Hasil uji statistik dengan Ancova, menemukan bahwa variabel pengetahuan awal secara signifikan berpengaruh pada peningkatan prestasi akademik mahasiswa dengan $\mathrm{F}=26,179 ; \mathrm{p}<0,01$.

Hasil uji prasyarat tentang kemiringan garis regresi antara kelompok harus sama dan dibuktikan dengan tidak adanya interaksi antara skor prates dan variabel kontrol dengan variabel strategi kognitif tidak terpenuhi. Hasil ini dapat dilihat hasil uji interaksi yang signifikan $(F=9,019 ; p>0,05)$. Artinya bahwa ada interaksi antara kelompok dengan variabel pengetahuan awal. Hal ini membuktikan bahwa sekalipun telah dilakukan kontrol secara statistik terhadap varaiabel pengetahuan awal, variabel ini tetap memiliki pengaruh yang kuat terhadap variabel perlakuan sebagiamana teori-teori yang telah diuraikan peneliti dalam pembahasan di awal. Sekalipun uji asumsi prasyarat uji interaksi yang dilakukan dalam penelitian ini tidak terpenuhi, peneliti tetap melanjutkan analisis dengan menggunakan Ancova. Alasan peneliti melanjutkan analisis berpijak kepada dua pendapat Azwar yaitu, pertama, bahwa analisis lanjutan dapat dilakukan tanpa harus melakukan pemeriksaan terlebih dahulu terhadap terpenuhi-tidaknya uji asumsi yang dilakukan, karena sekalipun data yang digunakan tidak sesuai dengan hasil uji asumsi, hasil analisisnya tidak selalu invalid. Dan kedua, tidak terdapat alasan kuat untuk meragukan kesesuaian antara model analisis dengan data yang dimiliki tehnik-tehnik analisis statistika untuk tujuan pengambilan kesimpulan dapat digunakan tanpa uji asumsi. ${ }^{44}$

44 Saifuddin Azwar, Asumsi-asumsi dalam Inferensi Statistika. Buletin Psikologi. Tahun IX, No. 1, 2000, 4.

232 JURNAL LISAN AL-HAL 


\section{Pembahasan}

Penelitian ini bertujuan menguji efektivitas pemberian perlakuan penggunaan strategi kognitif membaca pemahaman untuk meningkatkan prestasi akademik mahasiswa pada matakuliah Pengantar Psikologi di Fakultas Dakwah Universitas A Situbondo. Uji statistik yang dilakukan menunjukkan hasil bahwa, pemberian perlakuan strategi kognitif pada kelompok eksperimen secara signifikan dapat meningkatkan prestasi akademik mahasiswa dari pada kelompok kontrol dengan nilai $\mathrm{F}=4,356$; $\mathrm{p}<0,05$. Hasil penelitian ini sejalan dengan temuan penelitian yang dilakukan oleh peneliti-peneliti terdahulu yang membuktikan bahwa strategi kognitif secara signifikan dapat meningkatkan prestasi pemahaman atau prestasi akademik. ${ }^{45}$

Temuan pada penelitian ini juga memperkuat teori strategi kognitif yang telah diulas peneliti dibagian awal tulisan ini. Perlakuan strategi kognitif yang dikenakan kepada kelompok eksperimen meningkatkan prestasi akademik mahasiswa secara signifikan ${ }^{46}$. Rendahnya prestasi akademik pada kelompok kontrol disebabkan karena mahasiswa dalam proses perkuliahan selama penelitian ini berlangsung tidak menerapkan strategi membaca seperti yang diberikan kepada kelompok eksperimen. Dengan kata lain, dapat dikatakan bahwa rendahnya prestasi kelompok kontrol karena kemampuan membaca yang rendah ${ }^{47}$.

Perlakuan strategi kognitif yang diberikan pada kelompok eksperimen memberikan manfaat dalam upayanya memperoleh informasi-informasi atau pengetahuan baru. Manfaat dimaksud yaitu bahwa strategi kognitif memberikan peluang pada individu untuk memanipulasi mental atau fisiknya untuk berinteraksi dengan tugas-tugas belajar. ${ }^{48}$ Penggunaan kemampuan berfikir penalaran merupakan salah satu cara belajar manipulatif dimana pembaca berfikir secara logis untuk menemukan berbagai informasi yang kompleks dalam suatu wacana sehingga tujuan belajar dapat dicapai. Kemampuan berfikir penalaran secara positif dan signifikan berpengaruh pada membaca pemahaman. ${ }^{49}$

Melalui perlakuan strategi kognitif yang dieksperimentasikan, kelompok eksperimen diarahkan untuk dapat mengatur strategi

${ }^{45}$ Ozek \& Civelek, Op. Cit, 1.

${ }^{46}$ Reza Aghaie \& Lawrence Jun Zhang, Effects of explicit instruction in cognitive and metacognitive readingstrategies on Iranian EFL students' reading performance and strategy transfer, Instructional Science, November 2012, 1063.

${ }^{47}$ Etfita, Op. Cit, 76.

${ }^{48}$ Chamot, Op. Cit, 25.

${ }^{49}$ Ngabut, , Op. Cit, 26. 
belajarnya agar mereka menggunakan kemampuan berfikir analitis dan sintesis. Strategi ini dilakukan agar mahasiswa pada kelompok ini menemukan informasi-informasi tersirat dengan cara memprediksi dan mengasosiasikan makna telah didapat untuk kemudian menghubungkan dan mengiinterpretasikan sehingga menjadi sebuah pemahaman komprehensif. Temuan ini sejalan dengan argumentasi Schunk yang menyatakan bahwa maksud dari mengatur strategi berfikir analitis dan sintesis yaitu untuk menentukan berbagai jenis informasi penting yang tertuang dalam wacana untuk kemudian digabungkan menjadi sebuah makna yang koheren. ${ }^{50}$

Pembaca yang baik akan membuat catatan atau catatan pinggir seperti kata kunci yang menjadi bagian penting terkait pesan atau pikiran utama dari wacana. Hal ini dilakukan untuk mengorganisasikan informasi dan memahami isi wacana dan menahan pesan atau informasi dalam memori. ${ }^{51}$ Strategi meringkas yang dilakukan kelompok eksperimen dapat membantu mempermudah pemahaman mereka melaui klasifikasi informasi-informasi penting dan kosa-kata atau frase. Kemudian, informasi-informasi tersebut direorganisasi untuk menghubungkannya dengan informasi-informasi baru yang sarat makna guna dielaborasi dan diorganisasikan untuk diintegrasikan dengan pengetahuan yang telah tersimpan dalam memori jangka panjang.

Temuan pada penelitian ini telah membuktikan bahwa strategi kognitif efektif dalam meningkatkan prestasi akademik. Untuk itu penelitian ini perlu dilakukan penelitian lanjutan karena menurut hemat peneliti, penelitian ini memiliki kelemahan yaitu peneliti bertindak juga sebagai pengajar matakuliah Pengantar Psikologi di tempat penelitian ini dilakukan. Penelitian ini juga perlu dikembangkan untuk terutama di lingkungan Universitas A tempat peneliti melakukan penelitian dengan subyek penelitian yang lebih luas dan dari semua jenjang pendidikan.

\section{E. Simpulan}

Temuan pada penelitian ini dapat disimpulkan bahwa penggunaan strategi kognitif dalam membaca pemahaman secara signifikan efektif meningkatkan prestasi akademik mahasiswa. Tingginya capaian prestasi akademik mahasiswa tersebut sebagai efek dari penerapan strategi kognitif yang memberikan kemudahan dalam memahami wacana yang ditelaahnya. Kemudahan menelaah wacana tersebut karena pembaca

${ }^{50}$ Schunk, Op. Cit, 328.

${ }^{51}$ Sahan, Op. Cit, 02.

234 JURNAL LISAN AL-HAL 
mampu melakukan penalaran guna menemukan informasi-informasi yang kompleks untuk dianalisis dan disintesakan. Pembuatan catatan, catatan pinggir, dan meringkas sebagai upaya melakukan reorganisasi informasi untuk memperkuat struktur pengetahuan yang diperolehnya. Berdasar temuan penelitian ini pula, peneliti menyarankan bagi para guru atau dosen untuk menerapkan strategi kognitif dalam membaca.

\section{DAFTAR PUSTAKA}

Abdul Gafur Marzuki, Nur Alim, \& Ismail Suardi Wekke, Improving the reading comprehension through cognitive reading strategies in language class of coastal area in Indonesia, Earth and Environmental Science, 2018.

Ahmet Şahan, Cognititive Reading Comprehension Strategies Employed by ELT Students, Sosyal Bilimler Enstitüsü Dergisi Sayı, 3, 2012.

Anna Uhl Chamot, Teaching Learning Strategies to Language Students. U.S. Departemnt of Education, Educational Resources Information Center (ERIC), 1998. Language Learning Strategy Instruction: Current Issues and Research, Annual Review of Applied Linguistics, 25, 2005.

Anne Ratna S, The Use of Cognitive Reading Strategies to Enhance EFL Students' Reading Comprehension, International Journal of Education, Vol. 2, 1, 2014.

Carol Booth Olson \& Robert Land, A Cognitive Strategies Approach to Reading and Writing Instruction for English Language Learners in Secondary School, Research in the Teaching of English, Vol. 41, 3, 2007.

Catherine Snow, Chair, Reading for understanding: toward a research and development program in reading comprehension, RAND, South Hayes Street, Arlington.

Dale H. Schunk, Learning Theories: An Educational Perspective. $6^{\text {th }}$ ed. Pearson Education, Inc. 2012.

Donna Park, A study of the Goodman socio-psycholinguistic approach to beginning reading instruction in a frstgrade classroom, ScholarWorks@UMass Amherst, University of Massachusets Amherst, 2014.

Fauzul Etfita, Improving Studens' Reading Comprehension of Descriptive Texts Through Cognitive Strategy at Grade VII-2 of SMPN 1 Indara Praja Tembilahan, Lingua Didaktika, Vol. 7. 2, 2014.

Fransisco Cano-Garcia \& Fernando Justicia-Justicia, Learning strategies, JURNAL LISAN AL-HAL $\mid 235$ 
styles and approaches: an analysis of their interrelationships, Higher Education, 27, 1994.

Ibrahim Mohamed Alfaki \& Ahmed Gumaa Siddiek, The Role of Background Knowledge in Enhancing Reading Comprehension, World Journal of English Language, 3, 4, 2013.

Imam Suyitno, Cognitive Strategies Use in Reading Comprehension and its Contri butions to Students' Achievement, IAFOR Journal of Education, Volume, 5, 3, 2017.

J. Michael O'Malley, Anna Uhl Chamot, dan Lisa Kupper, The Role of Learning Strategies in Second Language Acquisition: Strategy Use by Students of English. U.S. Army Research Institute for the Behavioral and Social Sciences, 1987.

Kenneth S. Goodman \& William D. Page, Reading Comprehension Programs: Theoretical Bases of Reading Comprehension Instruction in the Middle, Grades, Revised Final Report. National Institute of Education United States Department of Health, Education and Welfare. 1987.

Khalimi Romansyah, Strategi Membaca Pemahaman yang Efektif dan Efisien, DEIKSIS - Jurnal Pendidikan Bahasa dan Sastra Indonesia, 2017.

Lisa Jean Lawrence, Cognitive and Metacognitive Reading Strategies Revised: Implication for Instruction, The Reading Matrix, Vol. 7, No. 3, 2007.

Maria Novary Ngabut, Reading Theories and Reading Comprehension, Journal on English as a Foreign Language, Vol. 5, 2015.

Michael Pressley, John G. Borkowski \& Wolfgang Schneider, Cognitive Strategies: Good Strategy User Coordinate Metacognition and Knowledge, Annals of Cbild Development, Vol. 4, 1987.

Muhammad Rusni, Ikhwan Sawaty, \& Elihami, The Cognitive Strategies through the Reading Comprehension in Islamic Education, Prosiding Konferensi Nasional Ke- 6 Asosiasi Program Pascasarjana Perguruan Tinggi Muhammadiyah 'Aisyiyah (APPPTMA), 2017.

Noldy Pelengkahu, Hubungan antara Pengetahuan Awal dan Penguasaan Kosa-kata Terhadap Keterampilan Membaca Pemahamn Mahasiswa, Jurnal Pendidikan dan Kebudayaan, 063, 12, 2006.

Noureldin Mohamed Abdelaal \& Amal Saleh Sase, Relationship between Prior Knowledge and Reading Comprehension. Advances in Language and Literary Studies, Vol. 5, 6, 2014.

Nur Intan Asmara, An Analysis of Cognitive Reading Strategies Used in 236 JURNAL LISAN AL-HAL 
Reading Comprehension, Advances in Social Science Education and Humanities Research (ASSEHR), Vol. 82, 2017.

Panayiota Kendeou \& Paul van den BroeK, The effects of prior knowledge and text structure on comprehension processes during reading of scientific texts, Memory \& Cognition, 2007.

Rebecca L. Oxford, Language Learning Styles and Strategies: An Overview. Web.ntpu.tw/ language/workshop/read2. 2013

Reza Aghaie \& Lawrence Jun Zhang, Effects of explicit instruction in cognitive and metacognitive readingstrategies on Iranian EFL students' reading performance and strategy transfer, Instructional Science, November 2012.

Saifullah, Pengaruh Metode Learning Together Terhadap Prestasi Pemahaman Bacaan Siswa Pada Mata Pelajaran Bahasa Inggris di SMP, Tesis, Yogyakarta, UGM, 2012.

Saifuddin Azwar, Asumsi-asumsi dalam Inferensi Statistika. Buletin Psikologi. Tahun IX, No. 1, 2000.

Suriah Ampuni, Proses Kognitif Pemahaman Bacaan, Buletin Psikologi, Th. VI, No. 2, 1998.

Thomas Dicky Hastjarjo, Kausalitas Menurut Tradisi Donald Campbell, Bulletin Psikologi, 29, 1, 2015.

Williams, M. \& Burden, R. L, Psychology for language teachers: A social constructivist approach, Cambridge, Cambridge University Press, 1997.

Yesim Ozek \& Muharrem Civelek, A Study on the Use of Cognitive Reading Strategies by ELT Students, The Asian EFL Journal Professional Teachers Articles, 2006. 


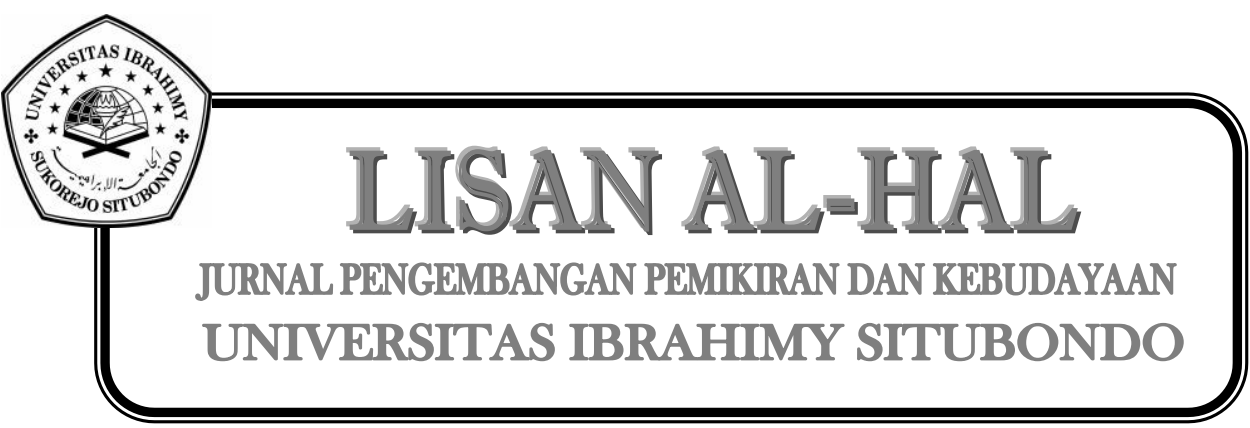

238 JURNAL LISAN AL-HAL 